\title{
CHRONOLOGY OF THE SOCIETY OF FRIENDS OF ASIAN ART FROM 1985-2010
}

In the previous Chronology of the Society, Maartje Draak (1907-1995), professor of Celtology and a board member for many years, unfurled the Society's history since it's founding from 1918 to 1985 . She mentioned the opening of the Society's own Museum of Asian Art in 1932 in several halls in the Stedelijk Museum Amsterdam and the ongoing collaboration with the Amsterdam Rijksmuseum that started in 1952, where the Society's famous collection has been housed ever since.

The last 25 years encompasses a considerably shorter period, but one that was extremely important for the Society. In the 1990s the permanent location of an important part of the collection, the Drucker Wing, was reorganised and renamed the South Wing. Because of the extensive renovation of the entire museum that started in 2003, this entire space is being used to exhibit 'The Masterpieces' - with a focus on 17th-century Dutch art - which will be displayed there until the museum reopens in 2013. Very few of the Society's icons have been exhibited in the Rijksmuseum during the last seven years but this will change dramatically when the new Asian Pavilion is completed. The Society's collecting policy has also changed, notably from 2000. Fewer gaps in the collection are filled and only the highest-quality objects are acquired; now the maxim for all the Rijksmuseum's sub-collections is 'Less is more'. This policy harmonises well with the direction the Society followed during the first few decades of its existence.

This particular episode began auspiciously in 1985 with the publication of the book Asiatic Art in the Rijksmuseum, Amsterdam, which was produced in its entirety by the Society and was edited by Pauline Lunsingh Scheurleer, curator of the Department of Asian Art.

In the same period, however, dark clouds gathered above the Society: the Ministry of Welfare, Health and Culture were planning to close down the Rijksmuseum's Department of Asian Art and transfer it to the National Museum of Ethnology in Leiden. These plans were initiated in 1981 and were revived at regular intervals. This would have meant that that the Society's collection, which forms the bulk of the collection of Asian objects at the Rijksmuseum, would also have to be relocated.

Providing a selection from the collection of Chinese ceramics to Leiden as a long-term loan temporarily averted this threat, but the debate persisted for several years at the Ministry about how merging 'Leiden' and 'Amsterdam' would be an improvement, and more importantly, would save money. To compound the issue, the Amsterdam city council announced that it wanted to end the modest financial contribution it had provided for a curatorship since 1952. The board of the Society managed to convince them otherwise, but the amount was not increased. 

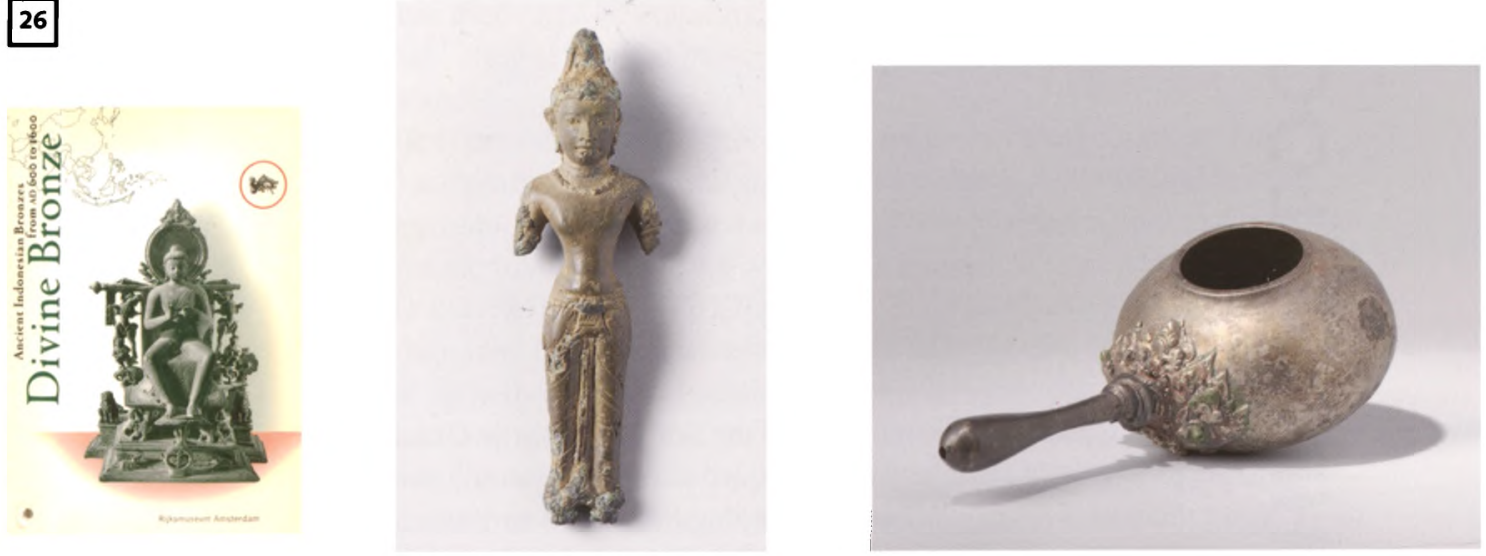

Figure 1

Catalogue of the exhibition 'Goddelijk Brons' ('Divine Bronze') in the Rijksmuseum, 1988.

\section{Figure 2}

Avalokitesvara, bronze, height $12 \mathrm{~cm}$, Sumatra, th-8th century, gitt of I. Polak to the Society of Friends of Asian Art, 1989, inv. no. AK-MAK1415.

\section{Figure 3}

Holy water ladle, silver, length $24.7 \mathrm{~cm}$, Indonesia, 13th-16th century, gift of J. Polak to the Society of Friends of Asian Art, 1990, inv. no. AK-MAK-1432.
Likewise, 1986 was a year of mixed messages. In Leiden the chair in East Asian Art History was discontinued after Professor H.A. van Oort retired. The Society's journal, Mededelingenblad, was renamed Aziatische Kunst (Asian Art), and was published in a more professional way. Businesses with ties to Asia were also approached as potential sponsors of the Society, with only scattered results. During this period information about Asian Art was published in instalments by the Openbaar Kunstbezit (Public Art Foundation), which shed more light on the activities of the Society and the conservators of Asian Art.

The exhibition 'Goddelijk Brons' ('Divine Bronze') provided a broad overview of the art of Indonesian bronze casting, and the associated symposium 'Ancient Indonesian Sculpture' was well attended by specialists from the field (fig. 1).

In 1989, Professor Henk van Os replaced Simon Levie as the general director of the Rijksmuseum. The Society and the Department did not have to wait on tenterhooks for long to discover the new director's position regarding Asian art in the Rijksmuseum. The annual report noted with great relief that Van Os 'wasted no time in publicly and voluntarily stating that retaining the department was of paramount importance'. In addition, that same year J.E. Loudon resigned as chairman and was replaced by the banker Michael Drabbe, who got along very well with the recently appointed general director.

In the meantime, the Society received many gifts. Mr and Mrs OorthuysLutjens donated a succession of Javanese works of art over a five-year period, and each year the art dealer Jaap Polak gave an object to the Society, including an 8th-century bronze Avalokiteshvara from Sumatra in 1989 and an Indonesian holy water ladle in 1990 (figs. 2 and 3).

In 1990 the management of the collection of Chinese and Japanese porcelain was transferred from the Department of Sculpture and Decorative Arts to the Department of Asian Art, and as a result the size and scope of their collection was substantially increased. The Department also benefited from the appointment of Klaas Ruitenbeek as the curator of East Asian Art in 1985. In 1990 the number of visitors to the Department of Asian Art in the Rijksmuseum amounted to more than 50.000 people.

The Society collaborated with De Nieuwe Kerk in Amsterdam on a comprehensive exhibition of Javanese sculpture in 1991, which included objects from the Society's collection. This exbibition was guest-curated by Jan J $_{44 \mathrm{AM}}$ Fontein, who served as the Society's curator until 1966 and afterwards free access 

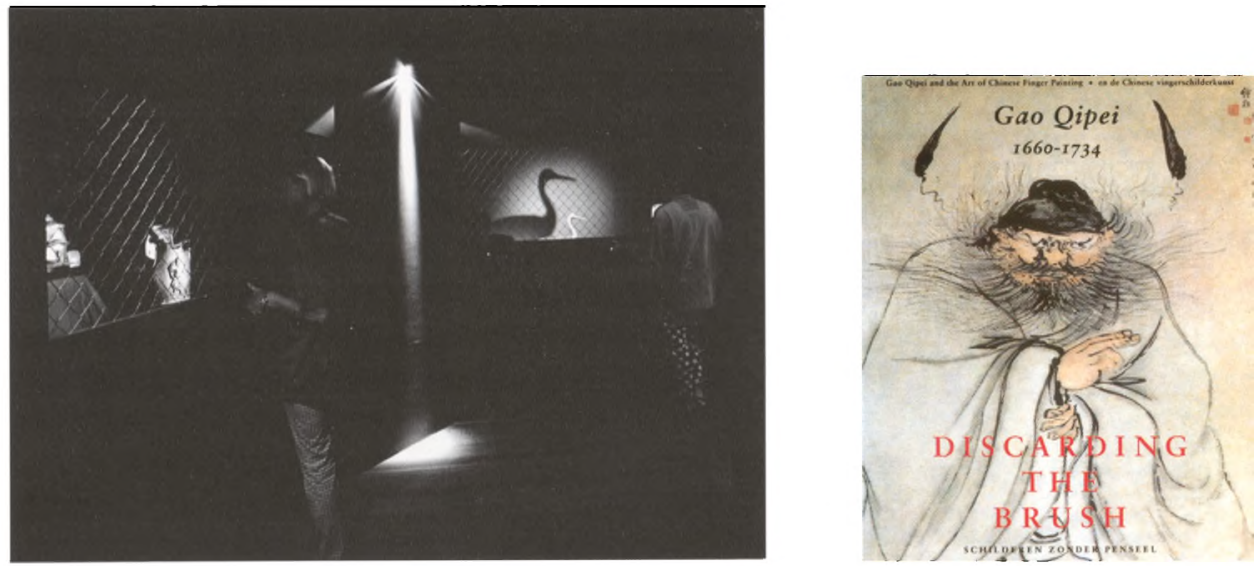

Figure 4

'Spiegel uit het Oosten' ('Mirror of the East'), exhibition in the Groninger Museum, 1992.

\section{Figure 5}

Catalogue of the exhibition 'Schilderen zonder penseel' ('Discarding the Brush') in the Rijksmuseum, 1992-1993.

\section{Figure 6}

Unkoku School, a pair of folding screens, Winter and Spring, colours on paper which is gilded with gold leaf, $180 \times 370$ cm, Japan, 1630-1660, jubilee acquisition by the Society of Friends of Asian Art, 1994, with additional funding from the Rijksmuseum Foundation and the Rembrandt Society, inv. no. AK-MAK-1464-A/B. worked as the director of the Museum of Fine Arts in Boston. Members had been asked to make a donation in the years preceding the 75 th anniversary of the Society, the intention being to acquire a truly outstanding object for the collection. The Acquisition Fund, established in 1929, had cash reserves of almost 255.000 guilders (almost 115.000 euros) in 1992. That same year the Drucker Wing was vacated for renovation and reorganisation and the Asian art was relocated to the Night Watch extension, where a small representative selection of 55 objects was temporarily displayed.

More objects from the collection were exhibited in the Groninger Museum, where the curator of Eastern and Western decorative arts, Christiaan Jörg, organised a loan exhibition (fig. 4). Furthermore, the Rijksmuseum's large winter exhibition of 1992/93 was dedicated to Asian Art. Titled 'Schilderen zonder penseel' ('Discarding the Brush'), it featured works by the Chinese finger-painter Gao Qipei (1660-1734), an album by whom is in the Society's collection (fig. 5).

The Society's 75th anniversary was celebrated in 1993 with a splendid programme for members and guests in the Rijksmuseum, which Jan Fontein opened with a speech about collecting Asian art in the 20th century. In his many lectures during the preceding 25 years, Fontein presented himself as the chronicler of the early history of the Society, and paid tribute to the founders and collectors associated with the Society. The text of his speech was published in the September issue of Aziatische Kunst, which, from then on, would be published with a full-colour cover, appear four times a year instead of five, and was more voluminous.
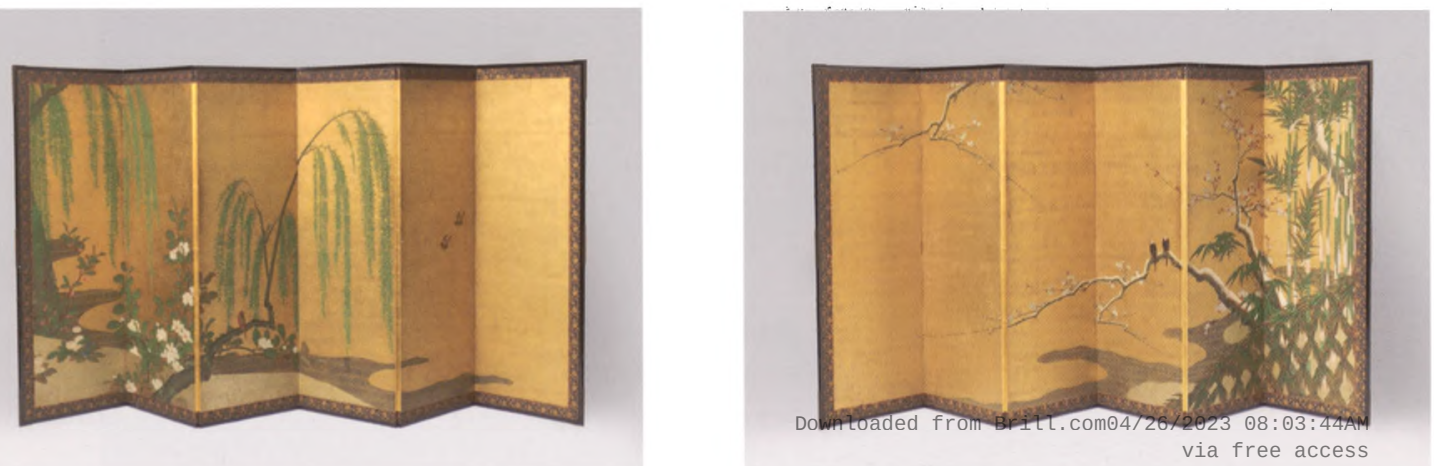
Figure $7>$

Indian miniature, polychrome painting, $31.5 \times 24.2 \mathrm{~cm}$, Marwar, Rajasthan, 4th quarter ITth century, gift of $P$. Formijne to the Rijksprentenkabinet, 1993, inv. no. RP-T. $1993-481$.

Figure $8 \gg$ Indian miniature, polychrome painting, $20.4 \times$ $13.7 \mathrm{~cm}$, circle of Mogul court artists, early ith century, gift of $P$. Formijne to the Rijksprentenkabinet, inv. no. 1993RP-T-1993-141.

Figure $9>$

Garuda, gilded copper, height $20 \mathrm{~cm}$, Nepal, 17th century, Maartje Draak Bequest to the Society of Friends of Asian Art, 1996, inv. no. AK-MAK-1509.

Figure $10 \gg$

Eisho, The Great

Kannon Temple in Asakusa, published by Watanabe, woodblock print, $39 \times 26.4 \mathrm{~cm}$, ca. 1925, Maartje Draak Bequest to the Society of Friends of Asian Art, inv. no. AK-MAK-1630.
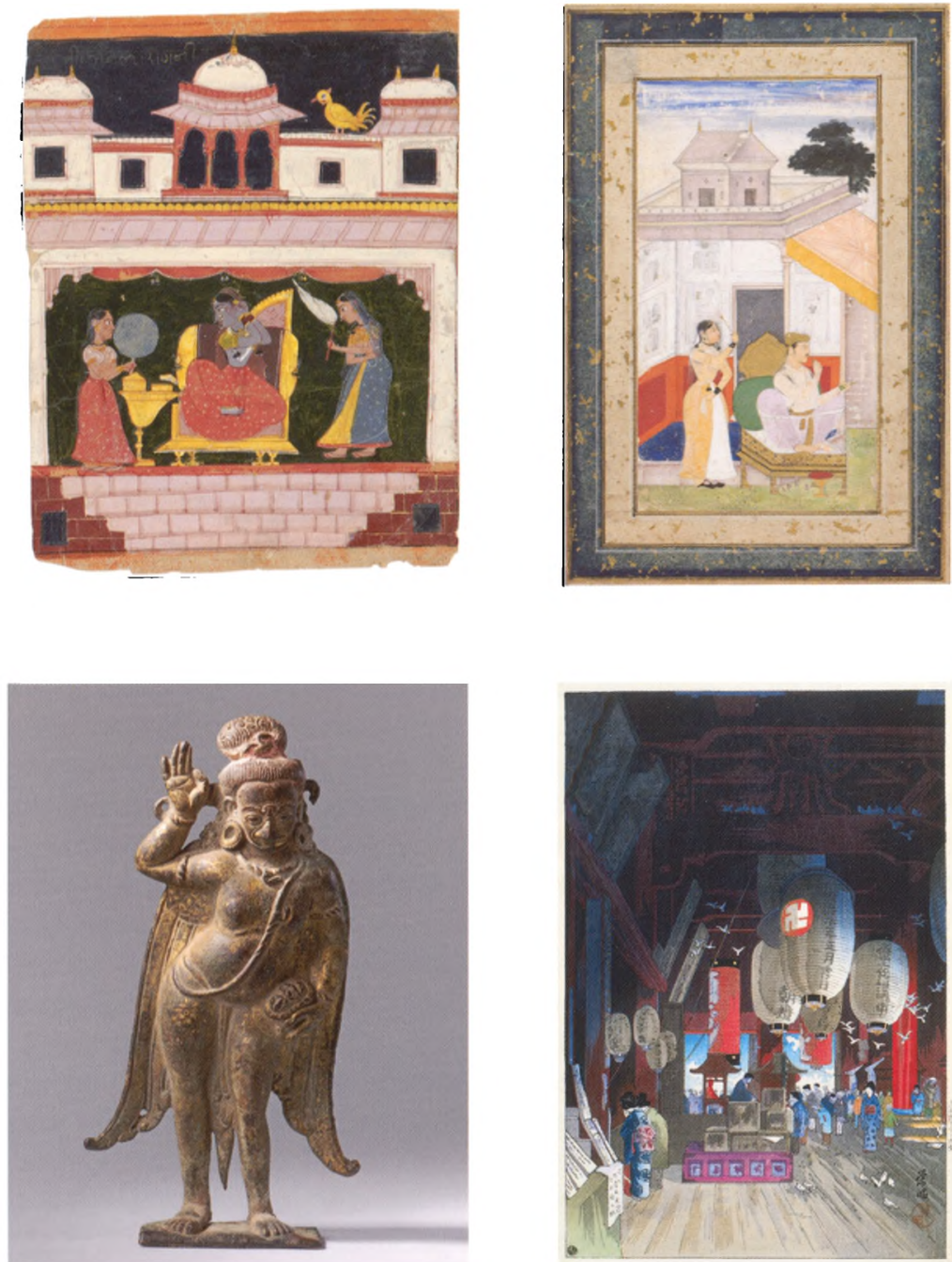

Although the Acquisition Fund now had 340.000 guilders in cash reserves (about 150.000 euros), which enabled the acquisition of several beautiful objects, no suitable 'icon' had been found that would complement the Society's high-quality collection. This wish was fulfilled one year later when the Society purchased two extraordinary Japanese folding screens by the Unkoku School (1630-1660). The screens are decorated with birds and blossoming branches painted on a gold ground (fig. 6).

De Nieuwe Kerk organised another large exhibition about Asia in 1993, which confirmed the growing interest in Asian cultures. Titled 'Het Goddelijk Gezicht van Indonesië' ('The Divine Face of Indonesia'), this exhibition was guest-curated by Jan Fontein. The Society and Pauline Scheurleer also worked on this exhibition, which was visited by more than 100.000 people.

Jan van Campen joined the Department of Asian Art in 1995, initially with a two-year appointment that included doctoral research into the collector Jean Theodore Royer, the subject of his graduation thesis in 2000. The Rijksmuseum $44 \mathrm{Am}$ held an exhibition about Royer's collection shortly afterwards. The Rijks ${ }^{r e e}$ access 
museum appointed Van Campen curator of Asian Export Art in 2001. The decision was also taken in 1995 to establish a chair in Material History of the Cultural Interactions between Asia and Europe. The Society sponsored the chair together with a private foundation that wishes to remain anonymous. Christiaan Jörg was appointed extraordinary professor in this chair in 1996 and held this function for 13 years.

The Formijne Gift, a collection of Indian miniatures and a library about Indian and Persian art, was gratefully received by the Rijksprentenkabinet (the Rijksmuseum's Print Room) in 1993, and substantially enlarged the collection (figs. 7 and 8). Sadly, Maartje Draak, the highly esteemed board member and passionate collector, passed away in 1995. In her will she stipulated that the Society should have first choice from her extensive collection of Asian art, and furthermore stated that the objects that the Society did not want could be put up for auction. In accordance with her final wishes, a quarter of the proceeds from this auction were given to the Society. The Society selected objects from this sizeable private collection for its own collection at the end of 1995 (figs. 9 and 10).

The opening of the South Wing, the former Drucker Wing, took place in 1996 and included a new presentation and layout for the Department of Asian Art (figs. 11 and 12). Eight halls were made available, and around 600 objects were exhibited there. One of the halls was dedicated to sculpture and combined - most unusually - Chinese funerary ornaments with Buddhist and

Figure 11 Asian art in the Rijksmuseum's South Wing, 1996.

\section{Figure 12}

Asian art in the Rijks. museum's South Wing, 1996. Hindu statues from several different, but related, cultural areas, including Indonesia, Cambodia, China and Japan. Paintings from these various Asian cultures were exhibited in the next hall. The remaining halls were filled with decorative art, ranging from bronze vessels and lacquerware to jewellery and ceramics. Unfortunately this spacious arrangement was dismantled again six years later when the main museum building closed for renovation and 'The Masterpieces' were relocated to the recently renamed Philips Wing (formerly the South Wing), a situation that prevails to this day.
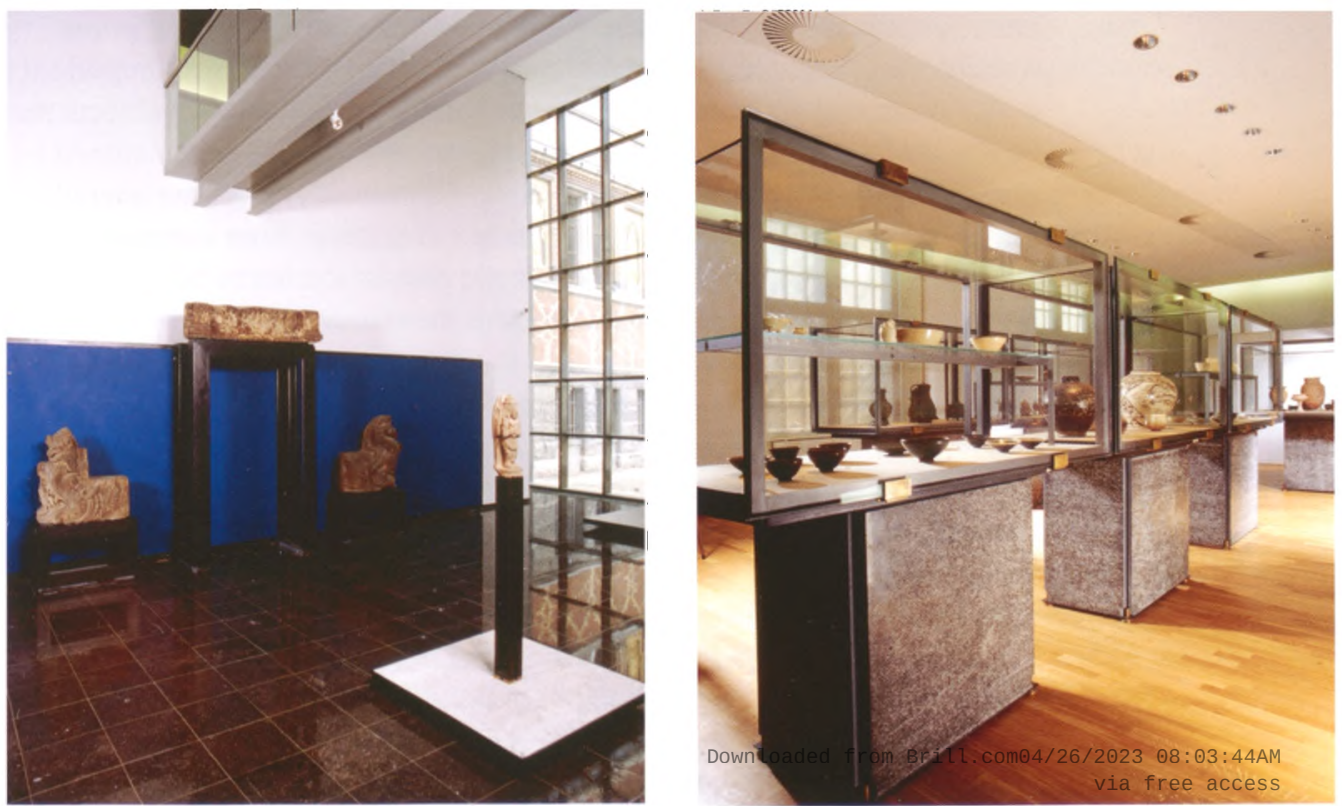

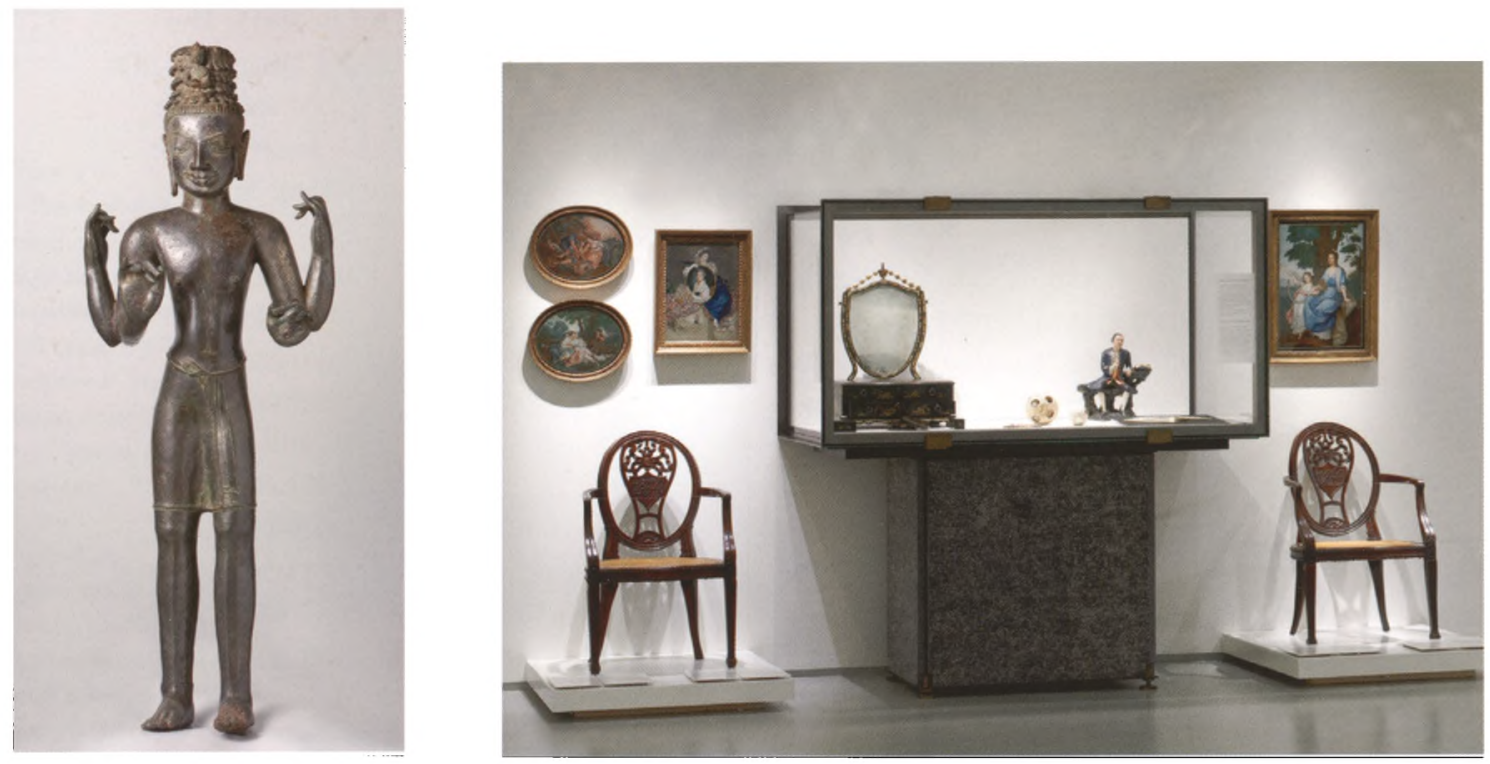

Figure 13

Avalokiteshvara, bronze, height $79 \mathrm{~cm}$, Prakhon Chai, Thailand, 3rd quarter 18th century, acquired by the Rijksmuseum, 2000, inv. no. AK-RAK-2000-15.

Figure 14

Presentation of objects from the Van Braam Houckgeest Collection in Museum CODA, Apeldoorn.
In 1996 Christiaan Jörg succeeded the highly respected Michael Drabbe - who passed away at a very young age - as chairman of the Society. To commemorate Michael Drabbe's membership of the Board of Directors, the ABN AMRO Bank established the M.J. Drabbe Fund for the Rijksmuseum's acquisitions in the area of Asian art. The next year Jörg and Van Campen published the collection catalogue Chinese Ceramics in the Rijksmuseum. All the objects discussed in the book were exhibited in the accompanying exhibition. The Rijksmuseum appointed a new curator of East Asian art in 1997, the Japanologist Menno Fitski.

The December 1997 issue of Aziatische Kunst was completely devoted to the Maartje Draak Bequest. The Society had selected and gratefully received a variety of objects from this bequest: Chinese ceramics, scroll paintings, Japanese porcelain and lacquerware, gilded bronzes from the Himalayan area, several ceramic objects from the Middle East and many Japanese woodblock prints. Although the Maartje Draak Bequest was an important gift, it also prompted an internal discussion about how to deal with objects that were not of interest to the Rijksmuseum, but which might be welcomed by other Dutch museums. However, this would probably affect the overall quality of and accessibility to the Society's collection. After extensive discussions it was decided to increase the objects loaned to other Dutch museums if the Rijksmuseum had to turn them down.

The year 2000 marked the 400-year anniversary of the relationship between Japan and the Netherlands and was commemorated with exhibitions, lectures and other events. As part of these celebrations, Menno Fitski, and the Society organised an exhibition featuring Japanese paintings from the Society's collection, which was accompanied by a special issue of the journal. The most important acquisition that year was an 8th-century four-armed, bronze Avalokiteshvara from Thailand, which was purchased with funds from the Sponsorloterij and others (fig. 13).

A small symposium held in 2001 focused on 'Collecting Art and Knowledge from Asia'. The interesting presentations by, among others, Frank Lequinee access 

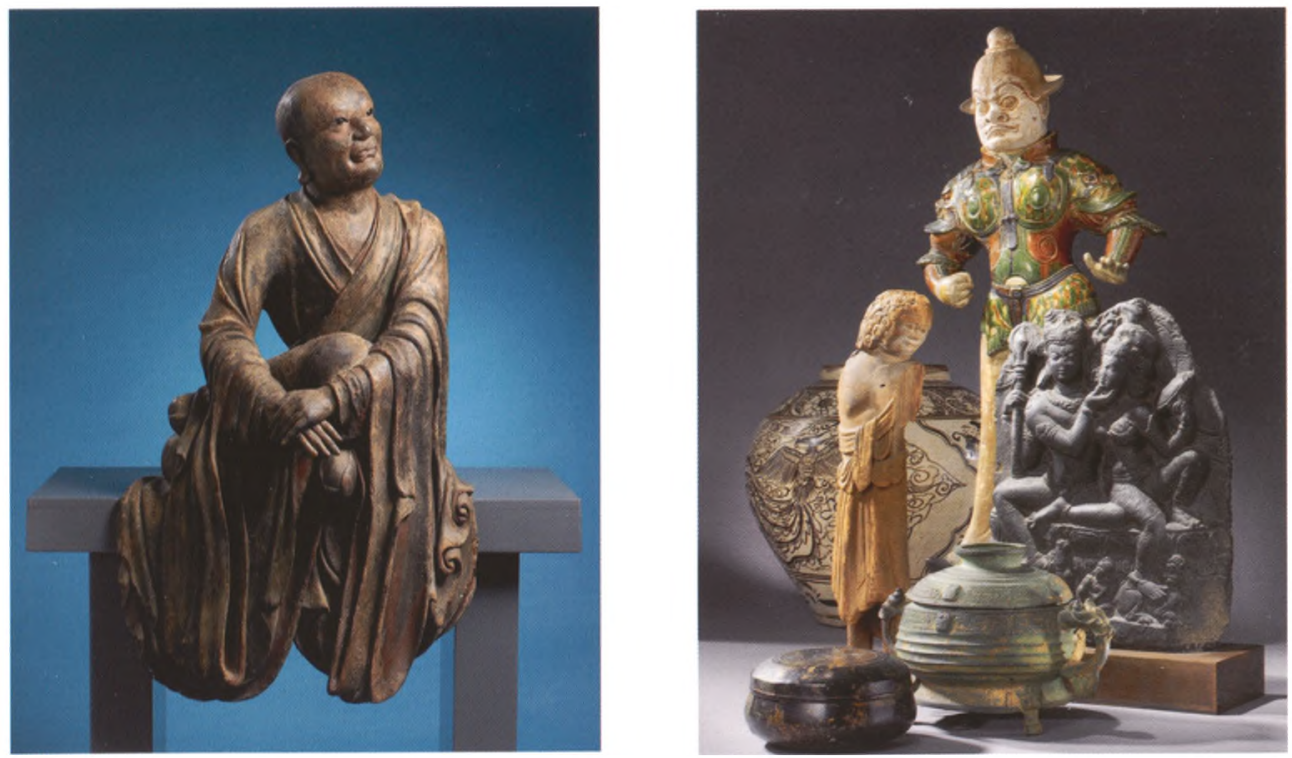

Figure 15

Lohan, wood with traces of a polychrome decoration, height 109 cm, China, 13th-14th century, acquired by the Society of Friends of Asian Art 2005, inv. no. AK-MAK-1727.

\section{Figure 16}

90-year jubilee of the Society in Museum Princessehof Leeuwarden, 2008. about the Titsingh Cabinet and by Matthi Forrer about Jan Cock Blomhoff, were published in the June issue of Aziatische Kunst.

In Apeldoorn the new museum CODA held an exhibition of Asian art titled 'Rijksmuseum op de Veluwe' ('Rijksmuseum on the Veluwe') in 2004 (fig. 14). It was wonderful to finally see the Society's icons again at this large exhibition featuring the collections of the Society and the Rijksmuseum: Guanyin, the Dancing Shiva and the voluptuous Indian temple statues. An expanded issue of Aziatische Kunst served as the lavishly illustrated catalogue. An exquisite 13th-century Chinese lohan was acquired for the collection in 2005 and is an important addition to the Society's collection of Chinese objects (fig. 15). In 2006 a presentation about the Japanese tea ceremony and the way that the Dutch drank their tea replaced part of the exhibition in Apeldoorn. The following year most of the Society's Asian highlights were returned to storage and the collaboration with Apeldoorn came to an end.

The Society celebrated its 90th anniversary in 2008 with lectures and an exhibition of 90 objects in the Princessehof in Leeuwarden, which the Society had received as gifts (fig. 16). A celebratory issue of the Society's journal cast light on the vital role played by the founders and donors to the Society, and also served as the catalogue to the exhibited objects. The exhibition series 'Verborgen schatten uit het bezit van Leden' ('Our Members' Hidden Treasures') opened in the Geelvinck Hinlopen House in Amsterdam and featured privately owned Chinese and Japanese art. Christiaan Jörg served as chairman of the Society for eight years, from 1996 to 2004, and was replaced by Herbert-Jan Hijmersma, who served for four years. Christiaan Jörg accepted the Society's request to serve as interim-chairman from 2008 to 2010. A significant reorganisation occurred in the same year: the number of Board members was reduced, and member's committees were established to broaden knowledge and to motivate members to become more engaged in the Society's activities. 

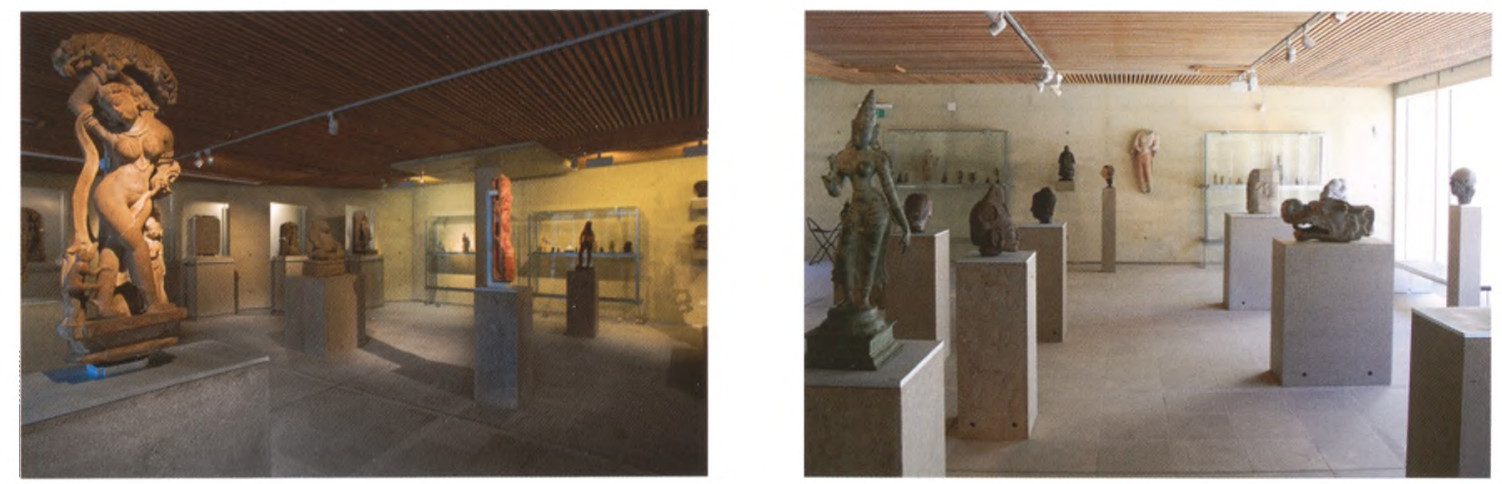

Figure 17

Presentation in Museum

Beelden aan Zee,

Scheveningen, 2008.

\section{Figure 18}

Presentation in Museum

Beelden aan Zee,

Scheveningen, 2008.
Pauline Lunsingh Scheurleer retired that same year after serving as the Society's curator of South- and Southeast Asian art for 34 years. The last exhibition in which she collaborated in this function was 'Hemelse beelden uit Oost en West' ('Heavenly Sculptures from the East and the West') in the Museum Beelden aan Zee in Scheveningen (figs. 17 and 18). This was also her farewell celebration and she was presented with her liber amicorum: the first edition of a special issue of Aziatische Kunst, titled Parels in een baaierd van lacunes (Pearls in a Chaotic Void). An international recruitment campaign is currently underway to find a suitable replacement for her function, which will be retained.

After years of preparation, the Asian Department could make one of the most spectacular acquisitions in its history in 2007: the 14th-century Japanese temple guardians. The Rijksmuseum bought these almost two-metre tall giants in Japan with additional funding from the Mondriaan Foundation, the BankGiro Lottery and the Rembrandt Society. The remaining balance from the M.J. Drabbe Fund was also used, a fitting and impressive finale for the fund (fig. 19).

The new function of curator of Indian Art in the Rijksmuseum is another important development, also for the Society. The steel foundry Corus will sponsor this curatorship from their Staal aan Zee Fund from 2009 for a period of ten years. Anna Slaczka, who studied Sanskrit and South Asian art at Leiden and who worked there as a lecturer at the Institute of Indology, holds this full-time position. That same year the Society established an Advisory Board, which can make unsolicited suggestions and offer advice to the Board. The Advisory Board is also responsible for raising funds for the Society.

It is noteworthy that the interest in Asian Art has increased dramatically over the last 25 years because more and more people travel to the Far East, and because of the increasing attraction of spirituality. However, the Society and the Rijksmuseum have not yet been able to assess this growth among the general public for the period that the Rijksmuseum has been undergoing renovations because almost all of their objects have been in storage.

Correspondingly, since the early 1980s dealers in Asian art have observed $\mathrm{a}_{3: 44 \mathrm{Am}}$ steep rise in prices of Asian art, certainly in Asian countries, where well-to-doccess 
entrepreneurs are buying back their countries' cultural heritage with everincreasing frequency.

This has given rise to a situation where most dealers in the West generally buy their objects from dealers and at auctions on the other side of the world. Prices in the countries of origin are now sometimes noticeably higher than in the West.

Having examined the period spanning 1985 to 2010, the last 25 years can in many ways be regarded as a transitional period. The Society has resumed its original, highly selective acquisition policy, as is evident from acquisitions like the Japanese folding screens, the Chinese lohan and the Japanese temple guardians, which have been included in the Rijksmuseum's collection as its new icons. The past few years have also seen the reorganisation and storage of the collection in preparation for its permanent accommodation in its own

Figure 19

A pair of temple guardians, wood with traces of a polychrome decoration, height 220 cm, Japan, 14th century, acquired with support from the M.J. Drabbe Fund, the Mondriaan Foundation, the BankGiro Lottery, the Rembrandt Society and the Prince Bernhard Cultural Foundation, inv. no. AK-RAK-2007-1A/B. pavilion close to the Museum Square (fig. 20). That four curators will soon be active in the Department of Asian Art is another promising development and a singular event not only for the Rijksmuseum and the Society but also rare at the international level. This underscores the importance that the collection has for the museum, particularly now that large general art museums such as the Louvre and the Metropolitan Museum of Art have started emphasising their collections of non-Western art.

The Society managed to maintain its position as a society with a steady membership of more than 500 people during this period, although the number of young members remains relatively low, a source of concern for many other societies, too.

The Aziatische Kunst journal has become a beautiful, well-produced quarterly journal with extremely informative essays by curators and specialists from the
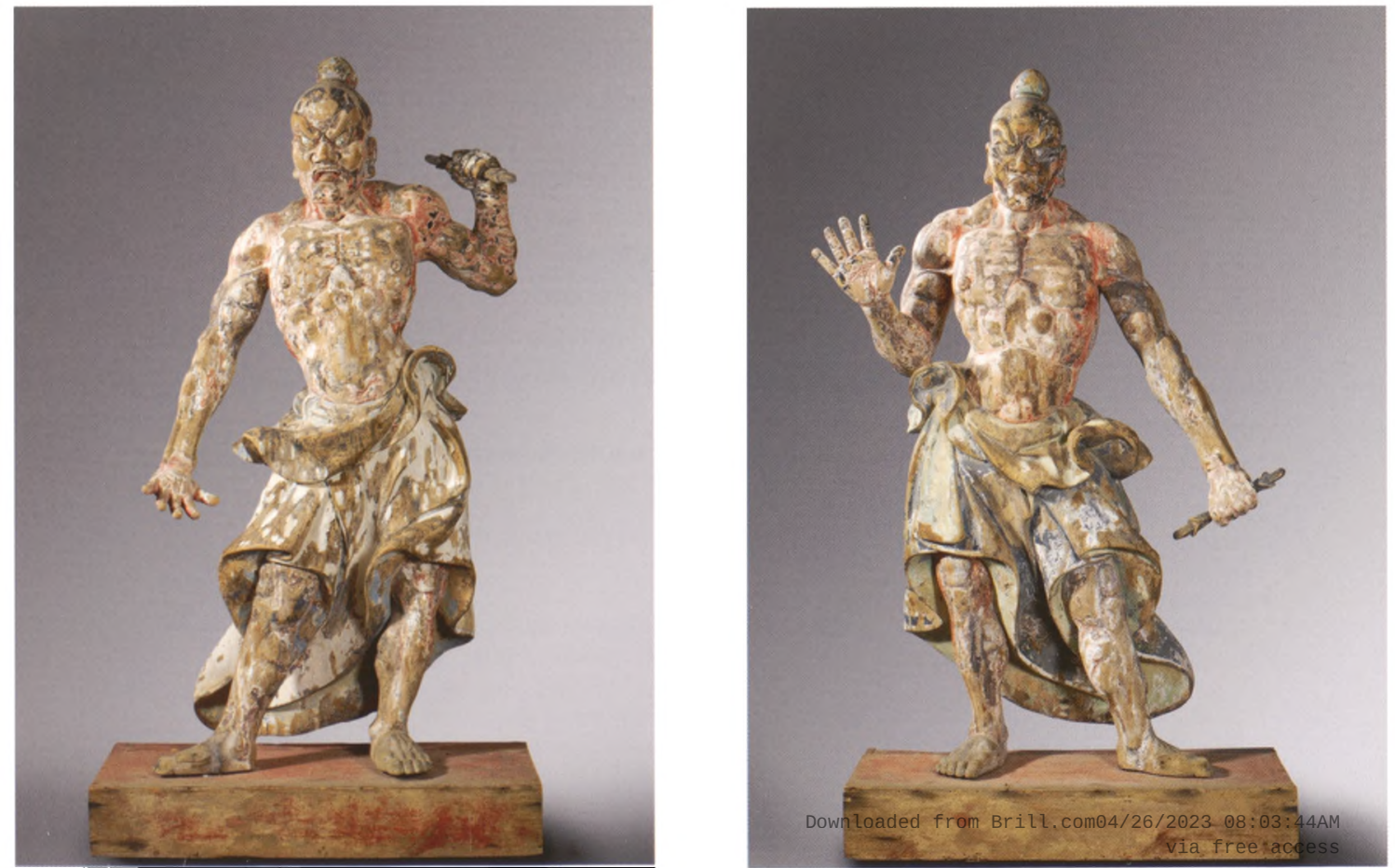


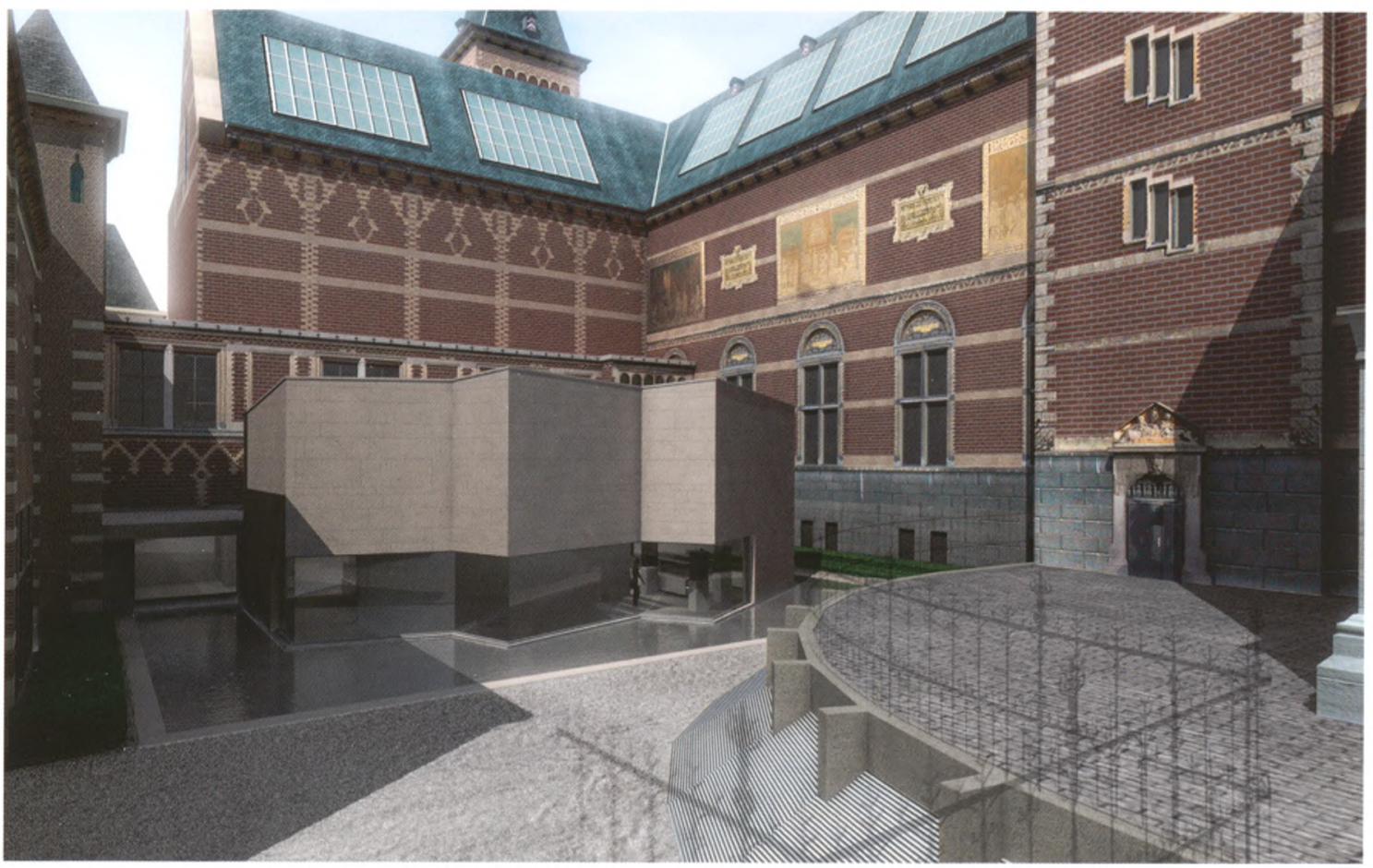

Figure 20

An impression of the Asian Pavilion by Cruz and Ortiz Architects. academic world. Ideally, the journal should be published in the English language, as this could expand its readership and distribution area, with a corresponding increase in membership. Members regularly discuss their collections in the journal, and recent acquisitions by members are exhibited in the Geelvinck Hinlopen House in an ongoing series of exhibitions that started in 2008. The Society continues to organise lectures, specimen meetings and excursions as a way of broadening its members' knowledge. Interactivity is an essential element for new, younger members who are not connoisseurs but who actively seek out knowledge and exchange ideas. They frequently collect objects associated with Asia, which means that the art - the objects themselves - becomes more important as the motivation for communication and interaction between members. This is why the Society is developing an interactive website with improved functionality and better images that facilitates the exchange of knowledge and experience. Over the course of the last few years, the management and organisation of the Society have become even more professional and have enhanced its international outlook.

When the Society's own small but beautifully designed Asian pavilion opens in a few years time, the Society's standing will certainly improve, and its old and recently acquired icons will be exhibited to the public in all their glory. 